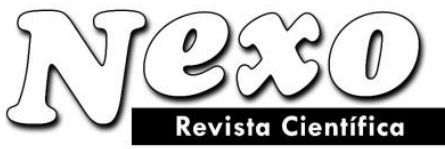

ISSN-E 1995-9516

Universidad Nacional de Ingeniería COPYRIGHT @ (UNI). TODOS LOS DERECHOS RESERVADOS

http://revistas.uni.edu.ni/index.php/Nexo

https://doi.org/10.5377/nexo.v34i06.13188

Vol. 36, No. 06, pp. 1867-1875/Diciembre 2021

(c) $(\mathrm{i})(\mathrm{SP})$

\title{
The use of logistics principles in the organization of local work
}

\section{El uso de principios logísticos en la organización del trabajo local}

\author{
Polina B. Romanova, Oksana A. Bondarenko, Natalia A. Mukovnina* \\ Samara State Transport University, Samara, Russia \\ *email: mykovnina-nata@mail.ru
}

(recibido/received: 28-octubre-2021; aceptado/accepted: 12-diciembre-2021)

\begin{abstract}
In the context of growing competition between rail transport and other transport types, there is a need to improve the transportation process. In modern conditions, railway transport is the main link in the logistics chain of moving goods from the shipper to the receiver. The efficiency of the railway transport complex can be improved by using logistics principles in the organization of local work on the network sections. In this study, we suggest ways to solve the problem of improving the quality of service for freight owners and the efficiency of organizing local work, which is relevant for railways. To make decisions aimed at improving the efficiency of the organization of local work, a procedure for determining the costs of organizing and promoting local trains was developed, taking into account the costs on maintaining the railway infrastructure. Not only the operational activity of the railways, but also the quality of transport customers service, compliance with the regulatory deadlines for cargo delivery, depends on the choice of the optimal option for organizing local car traffic into trains and their promotion along the section. The option is selected by comparing the costs for each of the possible options for organizing local car traffic into trains and moving them along the section.
\end{abstract}

Keywords: Car Traffic; Costs; Delivery Time; Local Work; Logistics; Railway Infrastructure.

\section{RESUMEN}

En el contexto de la creciente competencia entre el transporte ferroviario y otros tipos de transporte, es necesario mejorar el proceso de transporte. En las condiciones modernas, el transporte ferroviario es el eslabón principal de la cadena logística del traslado de mercancías desde el expedidor hasta el destinatario. La eficiencia del complejo de transporte ferroviario se puede mejorar utilizando principios logísticos en la organización del trabajo local en las secciones de la red. En este estudio, sugerimos formas de resolver el problema de mejorar la calidad del servicio para los propietarios de mercancías y la eficiencia de la organización del trabajo local, que es relevante para los ferrocarriles. Para tomar decisiones encaminadas a mejorar la eficiencia de la organización del trabajo local, se desarrolló un procedimiento para determinar los costos de organización y promoción de trenes locales, teniendo en cuenta los costos de mantenimiento de la infraestructura ferroviaria. No solo la actividad operativa de los ferrocarriles, sino también la calidad del servicio de transporte a los clientes, el cumplimiento de los plazos reglamentarios para la entrega de carga, depende de la elección de la opción óptima para organizar el tráfico local de automóviles en trenes y su promoción a lo largo del tramo. La opción se selecciona comparando los costos de cada una de las 
posibles opciones para organizar el tráfico local de automóviles en trenes y moverlos a lo largo de la sección.

Palabras claves: Tráfico vehícular; Costos; El tiempo de entrega; Trabajo local; Logística; Infraestructura ferroviaria.

\section{INTRODUCTION}

In the long-term development program of the open joint stock company "Russian Railways" until 2025, approved by the decree of the Government of the Russian Federation, the key initiative for the development of transport and logistics services is provided for: increasing the predictability of cargo delivery by improving transportation with agreed departure and arrival time, reducing delivery times (Medvedev, 2019). In modern conditions, railway transport is the main link in the logistics chain of cargo delivery. The use of logistics in railway transport makes it possible to increase the efficiency of the transport complex. The logistics principles are based on the choice of the most appropriate option for the functioning of the logistics system. It is necessary to con-sider management decisions that are optimal for the given parameters. In the conditions of growing competition of railway transport with other modes of transport, there is a need to improve the transportation process, including by reducing operating costs. On the railways, local trains make up 70\% of the total train traffic (Levin, 2018). Reducing operating costs is possible, among other things, due to an effective system of organizing local work. Not only the operational activity of the railways, but also the quality of transport customers service, compliance with the regulatory deadlines for cargo delivery, depends on the choice of the optimal option for organizing local car traffic to trains. A significant part of the operating costs is the costs associated with local work, which is an important element of the operational activities of the railways.

\section{METHODOLOGY}

The theoretical and methodological basis of the work was the works of leading scientists and specialists in the field of organizing local work on railway transport. In connection with the current conditions of the economic functioning of railways, in order to solve the problem of determining the options for organizing local car traffic into trains and moving them along the section, it is necessary to take into account the costs of maintaining the infrastructure. The technical, operational characteristics and operating technology of railway sections and stations were considered as the initial materials for the analysis of options. To build a mathematical model for describing the process of selecting options for organizing local work, it is necessary to know a number of characteristics of the calculated parameters: the capacity of the car traffic, the number of attached (uncoupled) cars at the intermediate stations of the section, the time the car is located on the section. Using the methods of mathematical statistics, the unevenness of loading and unloading of carriages at the intermediate stations of the considered sections was analyzed. The variable nature of the main design parameters should be taken into account. According to the available statistical data, the average values of the calculated parameters are determined. The average values represent the most likely number in a certain range, but they do not always characterize the dynamics of parameter fluctuations in the calculation period, which is quite high. Decisions on the choice of options for organizing local car traffic in trains should be made considering not only the average value of the parameters, but also the operational situation at the section stations. The optimal option is selected by comparing the costs for each of the possible options for organizing local car traffic into trains and moving them along the section.

\section{LITERATURE REVIEW}


Research in the field of organizing local work on railway transport was carried out by a number of major domestic scientists and specialists. Recently, the articles emerged considering local work in the new economic environment.

In the study (Levin, 2018), the presented model of the organization of work with local carriages is formulated in terms of the distribution of flows on graphs. Its algorithm arranges the arrival of wagons at the stations and the delivery to the freight fronts for ensuring the maximum possible size of freight operations. As a result of automation of operational planning of local and freight work, an operational plan is developed for the delivery of local carriages to stations and their delivery to the freight fronts. Such a plan includes the technology of formation and schedule of trains with local carriages and allows to monitor the progress of its implementation. Local work should be subordinated to the creation of optimal working conditions of freight fronts, which are characterized by the timely arrival of carriages at freight stations, the absence of irreparable losses of loading and unloading capabilities of freight fronts and ensuring the maximum size of loading and unloading.

Local work has an impact on the carrying capacity of the section. In the work (Timukhina, et al. 2020), in order to increase the economic efficiency of railway transport enterprises, it is suggested to use an approach according to which the interaction of infrastructure elements is taken into account when calculating the carrying capacity of the transport system.

The study (Sirina y Yushkova, 2020) analyzes the state of the transport infrastructure that provides the necessary volume of traffic. The presented provisions make it possible to make a rational choice on the use of infrastructure from a possible set of options, available resources and the needs of shippers.

Issues related to the organization of empty carriages by type of rolling stock and owners, possible places of their assembly are considered in the work (Frolova, et al. 2020). The analysis of the plan for empty carriages formation is carried out in order to identify stations for the concentration of empty carriages by types of rolling stock and routes to them. The analysis of groups of carriages that can be organized into routes is carried out. The criteria for optimizing the task for promoting empty carriages and improving the quality indicators of production performance for JSC "Russian Railways" are justified.

In the work (Pokrovskaya, 2020), a method was developed for assigning a logistics category to freight stations in accordance with the principles of customer orientation, availability and completeness of information. The method of assigning a logistics rating is also given, taking into account the specifics of the terminal and warehouse infrastructure and logistics services offered by the station. The classification of railway logistics objects with a given coefficient of complexity of transport and logistics services obtained in real conditions is suggested. The purpose of applying the methods in the transport sector is to implement the principles of customer-oriented logistics to ensure the profitability of freight transport and the redirection of goods from road transport to the objects of the railway terminal network.

On railways, there is an uneven shipment and delivery of cargo to the places of un-loading. The consentrated approach of empty carriages to the loading areas leads to unsatisfactory provision of loading with empty trains. In (Petruk y Zubkov, 2018; Zubkov, et al. 2020) works, the authors suggest a planning system for the successful organization of local work, starting from the moment of developing a monthly cargo loading plan, which should provide for the rhythm of their shipment, taking into account the unloading capabilities of the destination stations.

The problems of organizing local work are dealt with by specialists not only on domestic railways, but also abroad. The German National Center for Aerospace, Energy and Transport Research introduced the NGT Cargo freight train concept to the European freight rail market. The concept is aimed at the fastgrowing market of expensive and often urgent delivery of goods. Each carriage in the train will be equipped with a battery-powered traction installation, which allows for autonomous driving over a 
distance of about $25 \mathrm{~km}$ at a speed of $25 \mathrm{~km} / \mathrm{h}$ for delivering cargo along the "last mile" from the railway hub to the local terminal or customer point, as well as for performing shunting operations in production areas (Railways of the World, 2018).

In France, funds are allocated for the development of technological solutions on the use of railway vehicles for local distribution and collection of carriages. They are also creating a digital platform for monitoring trains running on railways, allowing customers to track cars. The platform will determine available working efficiency in trains, allowing companies to purchase seats on each other's trains, saving resources and reducing the number of tracks needed. This offer will allow operators to save a significant amount of money, especially when picking up and sending cars on the "last mile" (ERAI, 2021).

\section{RESULTS}

For the rational organization of local work on the section, it is necessary to establish the order of promotion of planned car traffic on the section. Currently, the organization of the delivery of local cargo is carried out by pick-up, sectional, export, transfer trains. The technology of organizing the order of promotion of planned car traffic on the site affects the turnover of the carriage. Carriages in local trains are additionally idle both at the formation stations and at the intermediate stations of the sections. As an example of late departure, Fig. 1 shows the results of the analysis of the number of pick-up trains sent from station $\mathrm{C}$ for 2020 . The percentage of pick-up trains sent on schedule was $88 \%$.

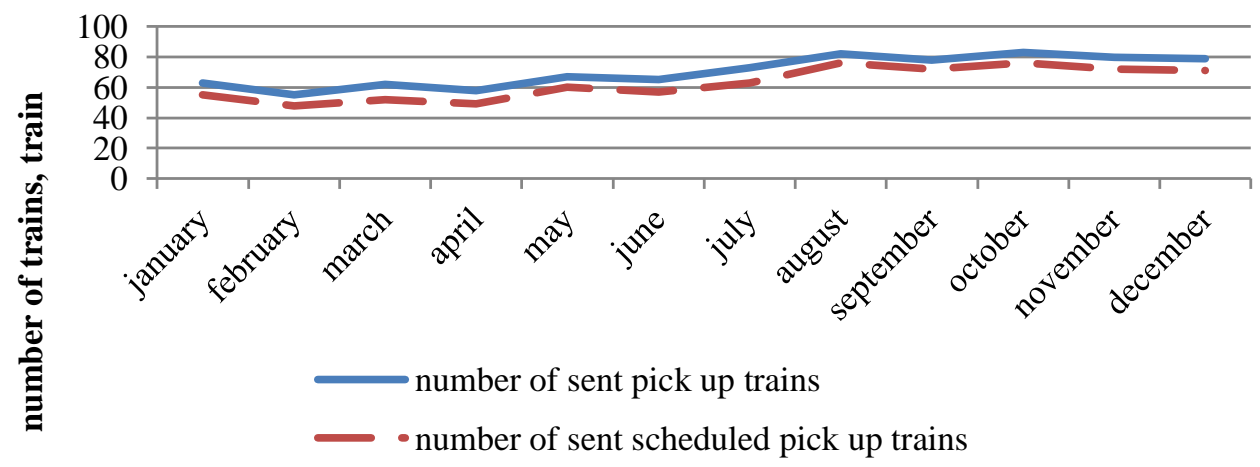

Figure 1. Analysis results of the number of pick-up trains sent from station C for 2020

The analysis of the components of the carriage turnover time showed that there is a tendency to increase the time spent by carriages at the intermediate stations of the section (Fig. 2).

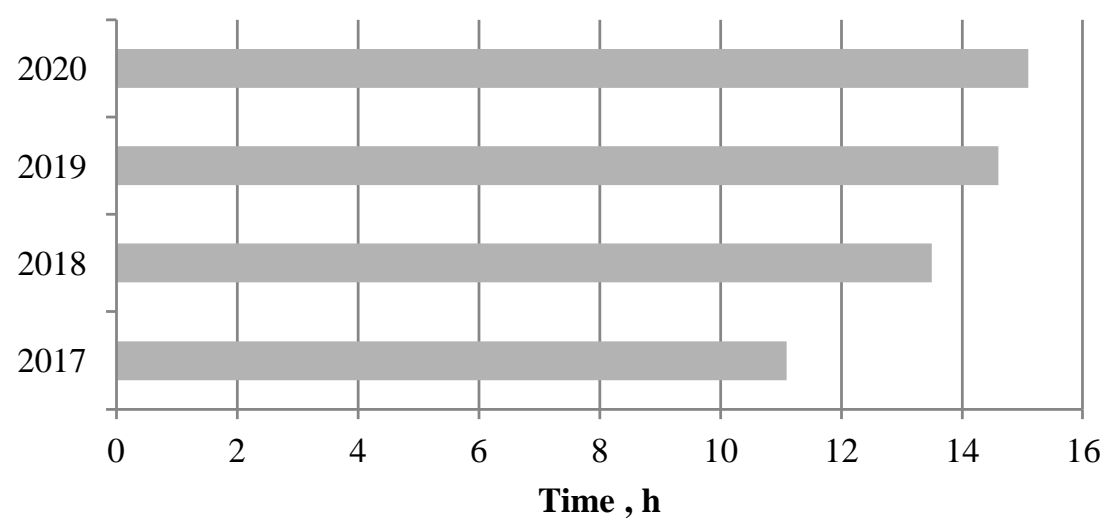

Figure 2. Results of the analysis of the idle time of the carriage at intermediate stations of the railway network. 
Additional idle time of carriages occurs due to the peculiarities of the technology of working with local car traffic. In most cases, several stations of the section are served by a single locomotive. Often, the number of shunting locomotives at the station does not correspond to the required amount of work. Reducing the time spent by cars at intermediate stations is achieved by quickly adjusting the order of movement along the section of local car traffic. Loading and unloading are, respectively, the initial and final operations in the logistics chain of cargo delivery by railway transport. The logistics chain of organizing the promotion of the carriage, from the station of formation of the local train to the destination station, also includes: accumulation; formation; relocation to the departure park, processing in the departure park, promotion along the section, shunting work. As a target function, the condition for minimizing the costs on organizing local car traffic in trains and their promotion along the section is accepted.

$$
F=E_{l w}^{i} \underset{i \in I}{\rightarrow} \min ,
$$

where $E_{l w}^{i}$ is the costs of organizing local car traffic in trains and their promotion along the section of the considered option $i(i=1 \ldots I)$,

$i$ is the number of possible options $i(i=1 \ldots I)$.

$$
E_{l w}^{i}=E_{a c}^{i}+E_{f}^{i}+E_{m w}^{i}+E_{p}^{i}+E_{m o v}^{i}+E_{s t}^{i}+E_{v}^{i}
$$

where $E_{a c^{-}}^{i}$ are the costs arising from the idle time of the carriage under the accumulation of the considered option $i(i=1 \ldots I)$, rub.;

$E_{f}^{i}$ - the costs arising from the idle time of the carriage in the system of formation of the considered option $i(i=1 \ldots I)$, rub.;

$E_{m w}^{i}$ - the cost of maneuvering work of the considered option $i(i=1 \ldots I)$, rub.;

$E_{p}^{i}$ - the cost on idle time of the carriage when preparing the train for departure of the considered option $i$ $(i=1 \ldots I)$, rub.;

$E_{\text {mov }}^{i}$ - the cost of moving along the section of the considered option $i(i=1 \ldots I)$, rub.;

$E_{s t}^{i}$ - the costs associated with the idle time of the carriage and the necessary shunting work at the stop stations of the pick-up train of the considered option $i(i=1 \ldots I)$, rub.;

$E_{v}^{i}$ - costs associated with the violation of the terms of delivery of goods of the considered option $i$ ( $i=$ $1 \ldots I)$, rub.

The procedure for determining the cost components for organizing and promoting local trains is presented in the study (Bondarenko y Mukovnina y Tretyakov, 2020). The option is selected by comparing the costs for each of the possible options for organizing local car traffic into trains and moving them along the section. An enlarged block scheme for selecting the optimal option for organizing local car traffic into trains and moving them along the section is shown in Fig. 3. 


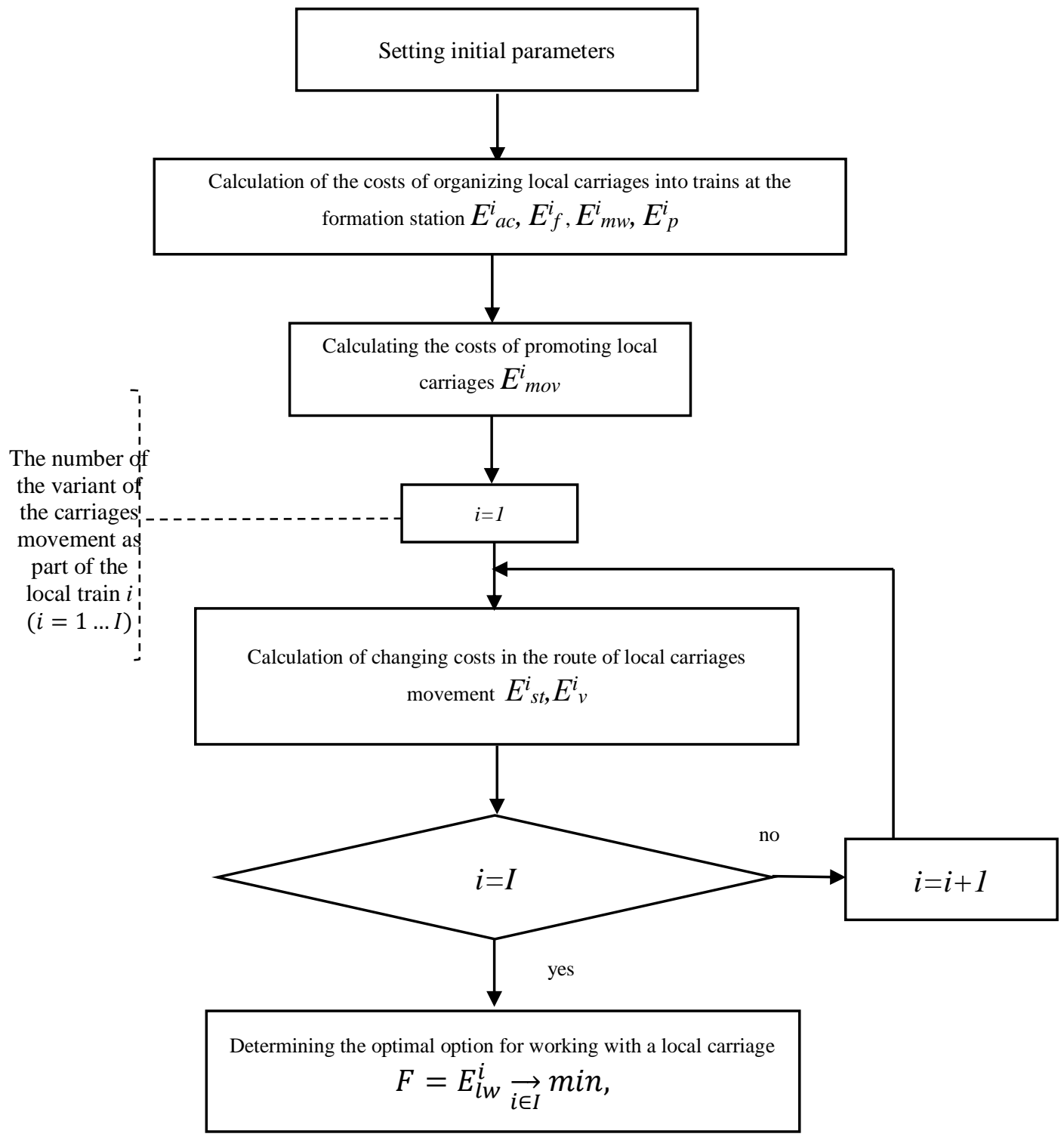

Figure 3. The enlarged block scheme of the optimal variant choice of the local car traffic organization in trains and their promotion on the section

As an example, let's consider the options for organizing local car traffic into trains and moving them along the A-B section. Delivery of local cargo on the A-B section is carried out by export, section and pick-up trains in accordance with the train formation plan. Local train formation stations (SF) and destination stations $(\mathrm{CH})$ are located on the section.

At station A, sectional trains are formed by the assignment to station B. Station B sends local cargo as the destination to the stations $1,2,3,4,5$ by local trains to the station 5 . Station 5 forms pick-up trains that have stops at stations 1, 2, 3, and 4 for attaching/uncoupling of carriages $(+\mathrm{N} /-\mathrm{N})$. The carriages assigned to station 4 from station A follow as part of the sectional trains to station B. After re-forming at the station $\mathrm{B}$, the carriages are followed as part of the sectional trains to station 5. Station 5 forms two pick-up trains per day, in which the carriages assigned to station 4 are located at the tail of the train. 
As a result of the analysis of the time spent on the route of the carriages, the destination to station 4 , it was found that the carriages get to the destination station in an average of two days, which significantly increases the delivery time. Also, for the departure of carriages from station 4, in the down direction, it is necessary to attach carriages $(+\mathrm{N})$ to the export trains following from stations 2 and 3 . The existing version of the organization of local work on the A-B section is presented in Table 1.

Table 1. The existing version of the organization of local work on the section A-B.

\begin{tabular}{cccccccccc}
\hline Formed local trains & Amount of traffic, train & \multicolumn{7}{c}{ Stations } \\
& & $\mathrm{A}$ & 1 & 2 & 3 & 4 & 5 & $\mathrm{~B}$ \\
\hline Pick-up 5-A & 2 & $\mathrm{CH}$ & $+/-\mathrm{N}$ & $-\mathrm{N}$ & $-\mathrm{N}$ & $+/-\mathrm{N}$ & $\mathrm{SF}$ & - \\
Export 2-B & 1 & - & - & $\mathrm{SF}$ & $\mathrm{x}$ & $+\mathrm{N}$ & $\mathrm{x}$ & $\mathrm{CH}$ \\
Export 3-B & 1 & - & - & - & $\mathrm{SF}$ & $+\mathrm{N}$ & $\mathrm{x}$ & $\mathrm{CH}$ \\
Sectional A-B & 5 & $\mathrm{SF}$ & $\mathrm{x}$ & $\mathrm{x}$ & $\mathrm{x}$ & $\mathrm{x}$ & $\mathrm{x}$ & $\mathrm{CH}$ \\
Sectional B-5 & 1 & - & - & - & - & - & $\mathrm{CH}$ & $\mathrm{SF}$ \\
\hline
\end{tabular}

In order to improve the efficiency of local work on the A-B section, the calculation of costs was made for possible options of organizing local car traffic into trains and their movement along the section, taking into account the costs of maintaining the railway infrastructure. Optimally, it is suggested to form four sectional trains and one pick-up train from station A, instead of five sectional trains. The carriages assigned to station 4 are not included to the sectional trains. The carriages assigned to the station 4 follow a separate group as part of a pick-up train. The pick-up train will stop at station 4 for uncoupling carriages assigned to station 4 and attaching carriages of down direction. It is also suggested to cancel one of the two pick-up trains running from station 5 to station A per day, since the carriages from station A will be delivered to station 4 by down pick-up train. The suggested option will allow export trains from stations 2 and 3 to proceed to station 4 without stopping and will ensure a stable departure of down carriages from station 4 . The best option for organizing local work on the A-B section is shown in Table 2.

Table 2. The best option for organizing local work on the A-B section.

\begin{tabular}{cccccccccc}
\hline Formed local trains & Amount of traffic, train & \multicolumn{7}{c}{ Stations } \\
& & $\mathrm{A}$ & 1 & 2 & 3 & 4 & 5 & $\mathrm{~B}$ \\
\hline Pick-up A-B & 1 & $\mathrm{SF}$ & $\mathrm{x}$ & $\mathrm{x}$ & $\mathrm{x}$ & $+/-\mathrm{N}$ & $\mathrm{x}$ & $\mathrm{SN}$ \\
Pick-up 5-A & 1 & $\mathrm{SN}$ & $+/-\mathrm{N}$ & $-\mathrm{N}$ & $-\mathrm{N}$ & $+\mathrm{N}$ & $\mathrm{SF}$ & - \\
Export 2-B & 1 & - & - & $\mathrm{SF}$ & $\mathrm{x}$ & $\mathrm{x}$ & $\mathrm{x}$ & $\mathrm{CH}$ \\
Export 3-B & 1 & - & - & - & $\mathrm{SF}$ & $\mathrm{x}$ & $\mathrm{x}$ & $\mathrm{CH}$ \\
Sectional A-B & 4 & $\mathrm{SF}$ & $\mathrm{x}$ & $\mathrm{x}$ & $\mathrm{x}$ & $\mathrm{x}$ & $\mathrm{x}$ & $\mathrm{CH}$ \\
Sectional B-5 & 1 & - & - & - & - & - & $\mathrm{CH}$ & $\mathrm{SF}$ \\
\hline
\end{tabular}

As a result of the analysis of the performed calculations, the optimal technology for organizing local car traffic into trains and their movement along the section was established. The economic effect from the introduction of the proposed technology of work is achieved by reducing the costs on organizing and following a single pick-up train, the costs associated with the idle time of the carriage and the necessary shunting work at the stations of train stops following the route 2-B and 3-B. The suggested technology makes it possible to reduce the delivery time of carriages assigned to station 4 by an average of a day. The economic effect will be 65479 rub. /day.

\section{CONCLUSION}

The Russian railways accumulated a big experience in organizing local work. The railways of European countries are also dealing with the problems of improving the efficiency of local work. The study provides an overview of the domestic and foreign scientists' studies in the field of organizing local work on railway 
transport. The decision making mechanism should be based on the basic principles of logistics. In modern conditions, when determining the optimal options for organizing local work, it is necessary to take into account the costs associated with the maintenance of the rail-way infrastructure. Due to the peculiarities of the technology of working with local car traffic, there are additional idle time of carriages at intermediate stations of the sections. The reduction in time spent on finding carriages is achieved by promptly adjusting the order of movement along the section of local car traffic. To make decisions aimed at improving the efficiency of the local work organization, a procedure for determining the costs on organizing and promoting local trains was developed. This procedure considers the costs on maintaining the railway infrastructure. Options for organizing local car traffic into trains depend on the capacity of the car traffic, the technical equipment of the section, the availability of shunting facilities at intermediate stations, and the capacity of the section. The option is selected by comparing the costs for each of the possible options for organizing local car traffic into trains and moving them along the section.

\section{REFERENCES}

Bondarenko, O.A., Mukovnina, N.A., Tretyakov, G.M. (2020). The procedure for determining the costs of organizing and promoting local trains. Bulletin of Transport of the Volga Region, 3, 50-55.

ERAI. (2021). Can France double rail freight volumes in 10 years? Available at: https://index1520.com/analytics/smozhet-li-frantsiya-udvoit-obemy-zheleznodorozhnykhgruzoperevozok-v-sleduyushchie-10-let/ last accessed 2020/11/16

Frolova, O., Shirokova, V., Kalikina, T., Melnik, I. (2020). Organization and movement of exit routes from empty cars. In: Popovic, Z., Manakov, A., Breskich, V. (eds.) VIII International Scientific Siberian Transport Forum. TransSiberia 2019. Advances in Intelligent Systems and Computing, 1116, 999-1010. Springer, Cham.

Levin, D.Yu. (2018). Adaptation of the organization of local work to modern conditions. Bulletin of the Research Institute of Railway Transport, 77(1), 18-26.

Medvedev, D. (2019). Long-term Development Program of Open Joint Stock Company "Russian Railways" until 2025: Approved by Order of the Government of the Russian Federation No. 466-r of 19.03.2019. Available

at: http://static.government.ru/media/files/zcAMxApAgyO7PnJ42aXtXAga2RXSVoKu.pdf. Last accessed $\underline{2020 / 12 / 10 .}$.

Petruk, V.V., Zubkov, V.N. (2018). Improving the efficiency of the technology of local work at the landfill of the North Caucasus Railway in the conditions of its volume growth. In: International Scientific and Practical Conference Science and Education in the XXI Century, 2(1), 101-108.

Pokrovskaya, O. (2020). Logistics grading of railroad stations. In: Popovic, Z., Manakov, A., Breskich, V. (eds.) VIII International Scientific Siberian Transport Forum. TransSiberia 2019. Advances in Intelligent Systems and Computing, vol. 1116. pp. 1152-1161. Springer, Cham.

Railways of the World. (2018). NGT Cargo - Next-generation freight train. Available at: https://zdmira.com/articles/ngt-cargo-gruzovoj-poezd-sleduyushchego-pokoleniya last accessed 2020/11/14.

Sirina, N., Yushkova, S. (2020). Operation of Infrastructure and rolling stock at railway polygon. In: Popovic, Z., Manakov, A., Breskich, V. (eds.) VIII International Scientific Siberian Transport Forum. TransSiberia 2019. Advances in Intelligent Systems and Computing, 1115, 367-383. Springer, Cham. 
Timukhina, E., Osokin, O., Tushin, N., Koshcheev, A. (2020). Coordination of parameters of transport elements system in the conditions of lack of traffic and estimated capacity. In: Popovic, Z., Manakov, A., Breskich, V. (eds.). VIII International Scientific Siberian Transport Forum. TransSiberia 2019. Advances in Intelligent Systems and Computing, 1116, 1133-1142 Springer, Cham.

Zubkov, V., Ryazanova, E., Chebotareva, E., Bakalov, M., Gordienko, A. (2020) Capacity and traffic management on a heavy-traffic railway line. In: Popovic, Z., Manakov, A., Breskich, V. (eds.) VIII International Scientific Siberian Transport Forum. TransSiberia 2019. Advances in Intelligent Systems and Computing, 1116, 934-949. Springer, Cham. 